\title{
Bioequivalence Study of Amitriptyline Hydrochloride Tablets in Healthy Chinese Volunteers Under Fasting and Fed Conditions
}

This article was published in the following Dove Press journal:

Drug Design, Development and Therapy

\author{
You Zhai $\mathbb{D i D}^{1,2}$ \\ Lihua $\mathrm{Wu}^{1,2}$ \\ Yunliang Zheng ${ }^{1,2}$ \\ Minglan $\mathrm{Wu}^{1,2}$ \\ Yujie Huang ${ }^{1,2}$ \\ Qian Huang (D) $)^{1,2}$ \\ Jianzhong Shentu ${ }^{1-3}$ \\ Qingwei Zhao',2 \\ Jian Liu (D) ${ }^{1,2}$
}

'Research Center for Clinical Pharmacy, State Key Laboratory for Diagnosis and Treatment of Infectious Disease, The First Affiliated Hospital, College of Medicine, Zhejiang University, Hangzhou, People's Republic of China; ${ }^{2}$ Zhejiang Provincial Key Laboratory for Drug Evaluation and Clinical Research, The First Affiliated Hospital, College of Medicine, Zhejiang University, Hangzhou, People's Republic of China; ${ }^{3}$ College of Medicine, Zhejiang University, Hangzhou, People's Republic of China

Purpose: This study compares the pharmacokinetic and safety profiles between a new generic and a branded reference formulation of amitriptyline hydrochloride tablets, and assesses the bioequivalence of the two products in healthy Chinese volunteers to obtain sufficient evidence for the marketing approval of the generic drug.

Materials and Methods: A randomized, open-label, two-period crossover study (clinicaltrials.gov, NCT03646526) was conducted under both fasting and fed conditions in healthy Chinese volunteers (24 subjects/condition). Eligible subjects randomly received a single $25 \mathrm{mg}$ dose of either the test or the reference formulation, followed by a 3-week washout period. Blood samples were collected until $144 \mathrm{~h}$ following administration. The pharmacokinetic parameters were acquired based on the concentration-time profiles, including the areas under the plasma concentration-time curve $\left(\mathrm{AUC}_{0-\mathrm{t}}, \mathrm{AUC}_{0-\infty}\right)$, the peak plasma concentration $\left(\mathrm{C}_{\max }\right)$, the time to achieve $\mathrm{C}_{\max }\left(\mathrm{T}_{\max }\right)$, and the elimination half-life $\left(\mathrm{t}_{1 / 2}\right)$. The geometric mean ratios (GMRs) and the corresponding 90\% confidence intervals (CIs) of amitriptyline were acquired for bioequivalence analysis, and values of these parameters for nortriptyline were used for comparison of therapeutic outcomes. Safety assessments included laboratory tests, physical examination, vital signs, and incidence of adverse events (AEs).

Results: The values of $t_{1 / 2}$ and $T_{\max }$ for amitriptyline were not significantly different between the test and reference products under both fasting and fed conditions $(\mathrm{P}>0.05)$. The GMRs of $\mathrm{C}_{\max }, \mathrm{AUC}_{0-\mathrm{t}}$, and $\mathrm{AUC}_{0-\infty}$ between the two products, and corresponding $90 \%$ CIs, were all within the range of $80 \%$ to $125 \%$ under both fasting and fed conditions. The test and reference products were well tolerated and did not elicit serious adverse events.

Conclusion: This study demonstrated that the generic and reference products were well tolerated by the subjects and bioequivalent, according to the rate and extent of the drug absorption.

Keywords: bioequivalence, pharmacokinetics, amitriptyline hydrochloride, nortriptyline

\section{Introduction}

Research Center for Clinical Pharmacy,

State Key Laboratory for Diagnosis and

Treatment of Infectious Disease, Zhejiang

Provincial Key Laboratory for Drug

Evaluation and Clinical Research, The

First Affiliated Hospital, College of

Medicine, Zhejiang University, 79

Qingchun Road, Hangzhou 310003 ,

People's Republic of China

Tel $+8657 \mid 87236537$

Fax +86 571 87214223

Email lindaliu87@zju.edu.cn
Depression is a major mental health disorders, which affected more than 300 million people in 2015. The World Health Organization (WHO) estimates that depression is the leading cause of disability and results in high morbidity, high suicide rates, and low clinical treatment rates worldwide. ${ }^{1}$ Various antidepressants, which are now available, are effective in treating depression, including tricyclic antidepressants (TCAs), monoamine oxidase inhibitors, selective serotonin reuptake inhibitors, serotonin-noradrenaline reuptake inhibitors, selective noradrenaline reuptake inhibitors, and noradrenergic and 
specific serotonergic antidepressants. ${ }^{2,3}$ Antidepressants were the 3rd most frequently prescribed drugs to individuals in the United States between 2005 and 2008. ${ }^{4,5}$ In addition, TCA amitriptyline has been regarded as one of the reference compounds for depression treatment. ${ }^{6}$

Amitriptyline, the most commonly used TCA, has a strong sedative effect and is primarily used to treat anxiety or agitated depression. Furthermore, it is slightly more effective than other TCAs or newer compounds. ${ }^{7,8}$ Amitriptyline was initially used in 1961 where it replaced imipramine soon after. ${ }^{9}$ Amitriptyline was the 3 rd most frequently used antidepressant in Germany in 2008, corresponding to 94 million daily doses. ${ }^{10}$ According to a large primary care-based prescription database in the UK, approximately 13 in every 1000 individuals were prescribed amitriptyline for depression treatment in $2010 .{ }^{11}$ To date, it is one of the most commonly used antidepressants included in the WHO's list of essential drugs. ${ }^{12}$ Currently there are more than 20 types of antidepressants mentioned in the Chinese national essential drug list. However, only amitriptyline and doxepin are primarily prescribed by primary care physicians. ${ }^{13}$

During amitriptyline metabolism, its side chain oxidizes producing a secondary amine nortriptyline, an N-oxide amitriptylinoxide (AT-NO), and a primary amine. ${ }^{14,15}$ Also, the demethylation of amitriptyline to the secondary amine nortriptyline does not result in its inactivation. Therefore, nortriptyline, which also has antidepressant and antinociceptive activities, subsequently became available. ${ }^{14}$ It is believed that the activities of amitriptyline and its active metabolite, nortriptyline, are primarily but not entirely due to their binding to the noradrenaline and serotonin transporters at central sites. ${ }^{16}$ In addition to major depression, amitriptyline was also reported to treat chronic neuropathic pain (pain due to nerve damage), ${ }^{17,18}$ fibromyalgia ${ }^{19}$ migraine, and anxiety disorders. ${ }^{20,21}$

Although amitriptyline hydrochloride has been widely used in China for several years, only a limited number of reports have studied its efficacy and tolerability during treatment of depressive disorders or other diseases. Thus, the pharmacokinetic data of this drug are limited. Recently, a generic amitriptyline hydrochloride product has been developed by Hunan Dongting Pharmaceutical Co., Ltd., (Hunan, China). Consistent with National Medical Products Administration guidelines, we compared the bioavailability of the new amitriptyline hydrochloride tablets with the reference product, manufactured by Sandoz Inc. and listed in the FDA orange book in 2016. This study was performed in healthy Chinese subjects, under fasting and fed conditions, to support the marketing approval of the newly developed generic formulation in China.

\section{Materials and Methods Study Drugs}

The amitriptyline hydrochloride test product was obtained from Dongting Pharmaceutical Co., Ltd, Hunan, China (batch number XB170502, expiry date 2019/04). Meanwhile, the reference product was purchased from Sandoz Inc., US (batch number HB3649, expiry date 2020/04).

\section{Subjects}

Healthy male and female Chinese adults, aged 18 to 45 years, with body mass indexes (BMIs) ranging from 19 to $26 \mathrm{~kg} / \mathrm{m}^{2}$, and weights higher than 45 and $55 \mathrm{~kg}$ for females and males, respectively, were recruited. All participating subjects signed informed consent forms (ICFs) after receiving information and confirmed understanding of the study's nature, objectives, procedures, possible risks, and requirement for study completion. All subjects were subjected to a comprehensive medical examination to evaluate their health conditions, including routine physical examination, detailed medical history, routine clinical laboratory test (including analyses of the blood, coagulation function, urine, and immunological system, and drug, alcohol, and nicotine tests), 12-lead electrocardiography (12-lead ECG), and chest X-ray. Only healthy subjects, who agreed to use contraceptive methods from 14 days prior to dosing to 6 months following the end of study, and fit the age, BMI, and weight criteria, and signed the ICFs, fulfilled the inclusion criteria and thus were randomized.

None of the subjects experienced any clinically significant abnormality during this study. Subjects with any history of allergy, sensitivity to any ingredient in the amitriptyline hydrochloride tablets, abuse of drug or alcohol, excessive smoking, or hepatic renal impairment were excluded. Subjects who used any drugs within 2 weeks before the first administration of amitriptyline hydrochloride, female subjects who were pregnant or lactating during the study, and subjects who suffered from any condition which could possibly affect the absorption of the drug were also excluded.

\section{Study Design and Treatment}

This study (ClinicalTrials.gov, NCT03646526) was performed at the Phase I Clinical Research Center of the 
First Affiliated Hospital, College of Medicine, Zhejiang University, China, in accordance with the Declaration of Helsinki, the Good Clinical Practice Guidelines of the International Conference on Harmonization, and other related guidelines. This study included two independent clinical trials (fasting and fed studies); each one was conducted using a randomized, open-label, single-dose, two-product, two-period crossover design. The research proposal was reviewed by the ethics committee of the First Affiliated Hospital, College of Medicine, Zhejiang University on February 8, 2018, and approved on March 20, 2018 (approval No. 2018-EC-38). The start and completion dates of the fasting and fed studies were August and September 2018, respectively.

All the subjects who were hospitalized on the day before the trial were randomly assigned to either group TR or group RT. Group TR received the test product in the first treatment period and the reference product in the second treatment period, while Group RT had the opposite administration sequence. These two treatment periods were separated by a 3-week washout phase. The randomization scheme was generated by the SAS software (version 9.4) in a 1:1 randomized block design. For subjects under fasting conditions, a single-dose test or reference product was orally taken with $240 \mathrm{~mL}$ warm water after fasting for at least $10 \mathrm{~h}$, while subjects under fed conditions had standard high-fat breakfast of about 800-1000 kcal (approximately 150, 250, and 500 600 kcal of protein, carbohydrates, and fat, respectively) starting $30 \mathrm{~min}$ before each drug administration and followed the same scheme. A thorough oral examination was performed after each drug administration to confirm oral film dissolution. The subjects were ambulatory, prohibited from vigorous activity, and closely supervised by qualified staff during the entire period of confinement. Water intake within $1 \mathrm{~h}$ before and after dosing was prohibited. Standard lunches and dinners were provided at the same time for both groups of the study, at 4 and $10 \mathrm{~h}$ after dosing.

\section{Blood Sampling and Analytical Determinations}

A series of blood samples were collected before and after each treatment period. Blood samples $(4 \mathrm{~mL})$ for pharmacokinetic analyses were collected into coded, $\mathrm{K}_{2}$-EDTA anticoagulation tubes at pre-dose (baseline) and at $0.5,1$, $2,3,4,5,6,7,8,10,12,24,36,48,72,96,120$, and 144 $\mathrm{h}$ post drug administration, and then centrifuged at $2000 \times$ $g$ and $4{ }^{\circ} \mathrm{C}$ for $10 \mathrm{~min}$ to separate the plasma. Plasma samples were temporarily stored at $-20{ }^{\circ} \mathrm{C}$ within $2 \mathrm{~h}$ of collection and transferred to an ultra-low temperature freezer $\left(-70 \pm 10^{\circ} \mathrm{C}\right)$ within $48 \mathrm{~h}$ for storage until analysis. In addition, all the collecting, processing, and storage procedures were performed under scarce light due to the photosensitive nature of the analytes. Plasma concentrations of amitriptyline and its metabolite nortriptyline were measured by the LC-MS/MS method, previously validated by CMIC (Suzhou) Pharmaceutical Technology Co., Ltd (Suzhou, China).

After performing a protein precipitation procedure, the quantitative determination of the target compounds was carried out in the positive ion mode and multiple reaction monitoring. Analytes were chromatographed by Shimadzu LC-30AD and analyzed by AB SCIEX tandem mass spectrometry Triple Quad 5500. Data were acquired with the analyst software, version 1.6.3. The linearity range of the detection method for amitriptyline and nortriptyline were $0.2-50 \mathrm{ng} / \mathrm{mL}$ and $0.1 \sim 25 \mathrm{ng} / \mathrm{mL}$, respectively. The lower limits of quantitation of amitriptyline and nortriptyline were $0.2 \mathrm{ng} / \mathrm{mL}$ and $0.1 \mathrm{ng} / \mathrm{mL}$, respectively. Additionally, $\mathrm{C}_{\max }$ and $\mathrm{AUC}_{0-\mathrm{t}}$ of amitriptyline were $18.7 \%$ and $14.9 \%$, respectively. Based on previous pre-test results from 12 subjects, $\mathrm{C}_{\max }$ and $\mathrm{AUC}_{0-\mathrm{t}}$ of amitriptyline were $23.48 \%$ and $18.95 \%$, respectively. Thus, the coefficient of variation in this study was considered as $24 \%$. Assuming a one-sided test with $\alpha=0.05$, accuracy of $0.8(\beta=0.2), \mathrm{CV}$ intra-subject $=24 \%$, a mean ratio of the test and reference product of 1.00 , and $90 \% \mathrm{CI}$ of $80.00 \% \sim 125.00 \%$ for the bioequivalence, 21 samples were required for testing, according to the PASS software (version 11.0.7). After considering the dropout rate, 24 subjects were enrolled for each study.

\section{Safety Assessment}

Safety assessments included laboratory tests, physical examinations, 12-lead ECG, vital sign measurement, and incidence of AEs. The laboratory tests included analyses of blood, coagulation function, urine, and immunological examination. Meanwhile, vital signs, such as blood pressure, pulse, temperature, and respiratory rate, were monitored before administration, as well as at 1, 4, 6, 8, 24, 48, $72,96,120,144 \mathrm{~h}$ after each drug administration to evaluate the safety of these two products. Any AEs occurring throughout the trial was recorded by research doctors and spontaneously reported by volunteers. 


\section{Pharmacokinetic and Statistical Analysis}

Amitriptyline pharmacokinetic parameters were calculated using the statistical software package SAS Enterprise Guide (V9.4) (SAS Institute Inc., Cary, North Carolina) and verified by performing the non-compartmental analysis with the Phoenix WinNonlin software, version 7.0 (Certara, L.P., St. Louis, MO). Plasma concentration-time curves were generated under both fasting and fed conditions where $\mathrm{C}_{\max }$ and $\mathrm{T}_{\max }$ were obtained. Meanwhile, $\mathrm{AUC}_{0-\infty}$ was calculated using the linear trapezoidal rule. $\mathrm{AUC}_{0-\infty}$ was calculated as the sum of $\mathrm{AUC}_{0-\mathrm{t}}$ and the extrapolated area from the last quantifiable concentration (Ct) divided by the elimination rate constant $\left(\lambda_{z}\right)$. T $1 / 2$ was calculated as $\ln 2 / \lambda_{z}$. The percentage of the extrapolated area (AUC_\%Extrap_obs) was obtained with the following formula: $\left[\left(\mathrm{AUC}_{0-\infty}-\mathrm{AUC}_{0-\mathrm{t}}\right) / \mathrm{AUC}_{0-\infty}\right] * 100 \%$. The relative bioavailability $(\mathrm{F})$ of the test product was calculated as: $\mathrm{F}=\mathrm{AUC}_{0-\mathrm{t}}($ test $) / \mathrm{AUC}_{0-\mathrm{t}}$ (reference) $* 100 \%$.

Statistical analyses were performed with the statistical software package SAS Enterprise Guide (V9.4) (SAS Institute Inc., Cary, North Carolina) using the noncompartmental pharmacokinetic analysis. $\mathrm{C}_{\max }, \mathrm{AUC}_{0-\mathrm{t}}$, and $\mathrm{AUC}_{0-\infty}$ were considered the main variables. The bioequivalence was determined by the factorial analysis of variance (ANOVA) for crossover design and calculating the $90 \%$ CIs of the ratio test/reference, according to the Chinese regulatory guideline. Therefore, ANOVA (PROC MIXED) evaluated the effects of the products, dosing sequence, trial period, and subjects nested within sequence by measuring the natural logarithm (ln)-transformed

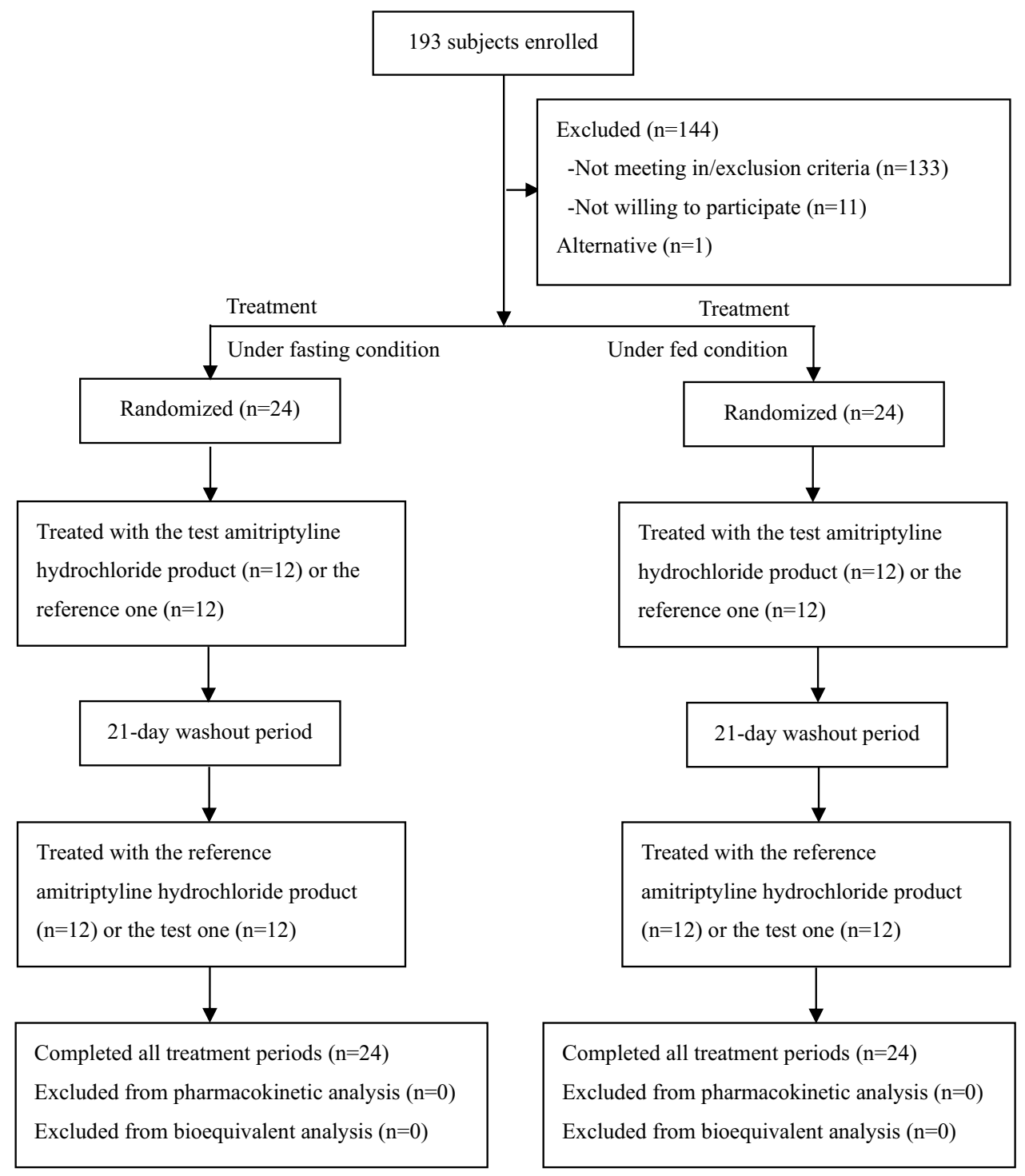

Figure I Study design and disposition of subjects. 
pharmacokinetic parameters $\left(\mathrm{C}_{\max }, \mathrm{AUC}_{0-\mathrm{t}}\right.$, and $\left.\mathrm{AUC}_{0-\infty}\right)$. Parametric $90 \%$ CIs of GMR between the two products (test-reference) were then calculated. Wilcoxon Signed Rank Test was used for $\mathrm{T}_{\max }$ and $\mathrm{t}_{1 / 2}$ assessments. If the $90 \%$ CIs of the $\mathrm{C}_{\max }, \mathrm{AUC}_{0-\mathrm{t}}$ and $\mathrm{AUC}_{0-\infty}$ GMRs fell within $80 \%$ to $125 \%$, the two products were considered bioequivalent.

\section{Results}

\section{Participants}

As shown in Figure 1, from Aug 7, 2018, to Sept 13, 2018, a total of 193 healthy Chinese adult potential subjects were screened. From among them, 48 were selected for the fasting and fed studies ( $n=24$ per group). Tables 1 and 2 summarize the demographic characteristics of all subjects.

\section{Pharmacokinetic Properties}

All 48 randomized subjects completed the studies and were included in the pharmacokinetic analyses for the reference or the test product. Under fasting conditions,

Table I Demographic Characteristics of Healthy Volunteers of the Fasted Study $(n=24)$

\begin{tabular}{|c|c|c|c|}
\hline \multirow[t]{2}{*}{ Variable } & \multicolumn{2}{|l|}{ Group } & \multirow[t]{2}{*}{ Overall $(n=24)$} \\
\hline & A: $\operatorname{TR}(n=12)$ & B: RT $(n=12)$ & \\
\hline \multicolumn{4}{|l|}{ Age, years } \\
\hline Mean (SD) & $29.58(8.370)$ & $24.15(4.835)$ & $26.87(7.238)$ \\
\hline $\operatorname{Min} \sim \operatorname{Max}$ & $21.0 \sim 42.5$ & $19.5 \sim 34.2$ & $19.5 \sim 34.2$ \\
\hline \multicolumn{4}{|l|}{ Height, cm } \\
\hline Mean (SD) & $165.4(7.96)$ & I 67.4 (9.54) & $166.4(8.65)$ \\
\hline $\operatorname{Min} \sim \operatorname{Max}$ & $|5| \sim \mid 75$ & $157 \sim 184$ & $|5| \sim \mid 84$ \\
\hline \multicolumn{4}{|l|}{ Weight, kg } \\
\hline Mean (SD) & $62.10(6.889)$ & 64.18 (8.819) & $63.14(7.811)$ \\
\hline $\operatorname{Min} \sim \operatorname{Max}$ & $52.8 \sim 74.7$ & $51.0 \sim 78.6$ & $51.0 \sim 78.6$ \\
\hline \multicolumn{4}{|l|}{ BMI (SD), $\mathrm{kg} / \mathrm{m}^{2}$} \\
\hline Mean (SD) & $22.69(1.730)$ & $22.83(1.931)$ & $22.76(1.794)$ \\
\hline $\operatorname{Min} \sim \operatorname{Max}$ & $19.4 \sim 24.9$ & $20.0 \sim 25.5$ & $19.4 \sim 25.5$ \\
\hline \multicolumn{4}{|l|}{ Sex } \\
\hline Male (\%) & $7(58.33)$ & $7(58.33)$ & $14(58.33)$ \\
\hline Female (\%) & $5(41.67)$ & $5(41.67)$ & $10(41.67)$ \\
\hline
\end{tabular}

Notes: $\mathrm{BMl}=$ weight $(\mathrm{kg}) /[\text { height }(\mathrm{M})]^{2}$; Group $\mathrm{A}=$ Test Amitriptyline hydrochloride of $25 \mathrm{mg}$ (Dongting Pharmaceutical Co., Ltd, Hunan, China) in the first treatment period and then reference Amitriptyline hydrochloride of $25 \mathrm{mg}$ (Sandoz Inc, US) in the second treatment period; Group B=Reference Amitriptyline hydrochloride of $25 \mathrm{mg}$ (Sandoz Inc, US) in the first treatment period and then test Amitriptyline hydrochloride of $25 \mathrm{mg}$ (Dongting Pharmaceutical Co., Ltd, Hunan, China) in the second treatment period.

Abbreviation: BMI, body mass index. nortriptyline AUC_\%Extrap_obs values of 5 subjects were greater than $20 \%$ in both periods. On the other hand, under fed conditions, nortriptyline AUC_\%Extrap_obs values of 2 and 1 subjects surpassed $20 \%$ in the 2 nd period and in both periods, respectively. These subjects were not included the calculation of the pharmacokinetic analysis of

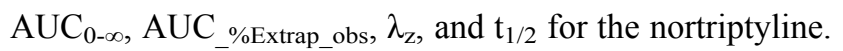
The mean plasma concentration-time profiles of amitriptyline and nortriptyline following a single oral administration of the test and the reference products under fasting and fed conditions are shown in Figures 2 and 3, respectively. Major pharmacokinetic parameters of amitriptyline and nortriptyline under fasting and fed conditions are summarized in Tables 3 and 4 , respectively. The $t_{1 / 2}$ of amitriptyline was about 32 to $38 \mathrm{~h}$ and that of nortriptyline was approximately $39 \mathrm{~h}$.

For bioequivalence evaluation, all the randomized 48 subjects were considered. Subjects whose nortriptyline AUC_\%Extrap_obs values exceeded $20 \%$ were not considered in the evaluation of the equivalence. The $90 \% \mathrm{CIs}$ for the GMR of pharmacokinetic parameters $\left(\mathrm{C}_{\max }, \mathrm{AUC}_{0-\mathrm{t}}\right.$, and $\left.\mathrm{AUC}_{0-\infty}\right)$ for both amitriptyline and nortriptyline

Table 2 Demographic Characteristics of Healthy Volunteers of the Fed Study $(n=24)$

\begin{tabular}{|c|c|c|c|}
\hline \multirow[t]{2}{*}{ Variable } & \multicolumn{2}{|l|}{ Group } & \multirow[t]{2}{*}{ Overall $(n=24)$} \\
\hline & A: $\operatorname{TR}(n=\mid 2)$ & B: RT $(n=12)$ & \\
\hline \multicolumn{4}{|l|}{ Age, years } \\
\hline Mean (SD) & 33.39 (8.533) & $27.36(8.131)$ & $30.38(8.7 \mid 4)$ \\
\hline $\operatorname{Min} \sim \operatorname{Max}$ & $21.9 \sim 44.7$ & $20.1 \sim 44.1$ & $20.1 \sim 44.7$ \\
\hline \multicolumn{4}{|l|}{ Height, cm } \\
\hline Mean (SD) & $165.5(7.18)$ & $166.2(8.01)$ & I $65.8(7.45)$ \\
\hline $\operatorname{Min} \sim \operatorname{Max}$ & $152 \sim 178$ & $153 \sim 178$ & $152 \sim 178$ \\
\hline \multicolumn{4}{|l|}{ Weight, kg } \\
\hline Mean (SD) & 61.61 (7.104) & $62.74(8.602)$ & $62.18(7.737)$ \\
\hline $\operatorname{Min} \sim \operatorname{Max}$ & $52.9 \sim 71.7$ & $51.4 \sim 76.1$ & $51.4 \sim 76.1$ \\
\hline \multicolumn{4}{|l|}{ BMI (SD), $\mathrm{kg} / \mathrm{m}^{2}$} \\
\hline Mean (SD) & $22.45(1.673)$ & $22.67(1.987)$ & $22.56(1.800)$ \\
\hline $\operatorname{Min} \sim \operatorname{Max}$ & $19.9 \sim 25.7$ & $19.2 \sim 25.4$ & $19.2 \sim 25.7$ \\
\hline \multicolumn{4}{|l|}{ Sex } \\
\hline Male (\%) & $9(75.00)$ & $8(66.67)$ & $17(70.83)$ \\
\hline Female (\%) & $3(25.00)$ & $4(33.33)$ & $7(29.17)$ \\
\hline
\end{tabular}

Notes: $B M l=w e i g h t(\mathrm{~kg}) /[\text { height }(\mathrm{M})]^{2}$; Group $A=$ Test Amitriptyline hydrochloride of $25 \mathrm{mg}$ (Dongting Pharmaceutical Co., Ltd, Hunan, China) in the first treatment period and then reference Amitriptyline hydrochloride of $25 \mathrm{mg}$ (Sandoz Inc, US) in the second treatment period; Group B=Reference Amitriptyline hydrochloride of $25 \mathrm{mg}$ (Sandoz Inc, US) in the first treatment period and then test Amitriptyline hydrochloride of $25 \mathrm{mg}$ (Dongting Pharmaceutical Co., Ltd, Hunan, China) in the second treatment period.

Abbreviation: BMl, body mass index. 
between the test and reference products were all within $80 \%$ to $125 \%$ under both fasting and fed conditions (Tables 5 and 6). Therefore, the test and reference products were considered bioequivalent.

\section{Safety Assessment}

During the study, all subjects received at least one dose of the study drug and were included in the safety analysis. During the fasting study, 83 AEs were recorded in all 24 subjects taking the test and reference products. The incidence of AEs of the test product was 100\% (24/24), while that of the reference drug was $91.67 \%$ (22/24). All AEs were mild and reported as grade 1, except for one case of serum triglyceride increase after drug administration, which was reported as grade 2 . In the fed study, 86 AEs were recorded in 24 subjects taking the test and reference products. The incidence of AEs of the test product was $95.83 \%(23 / 24)$; meanwhile, that of the reference
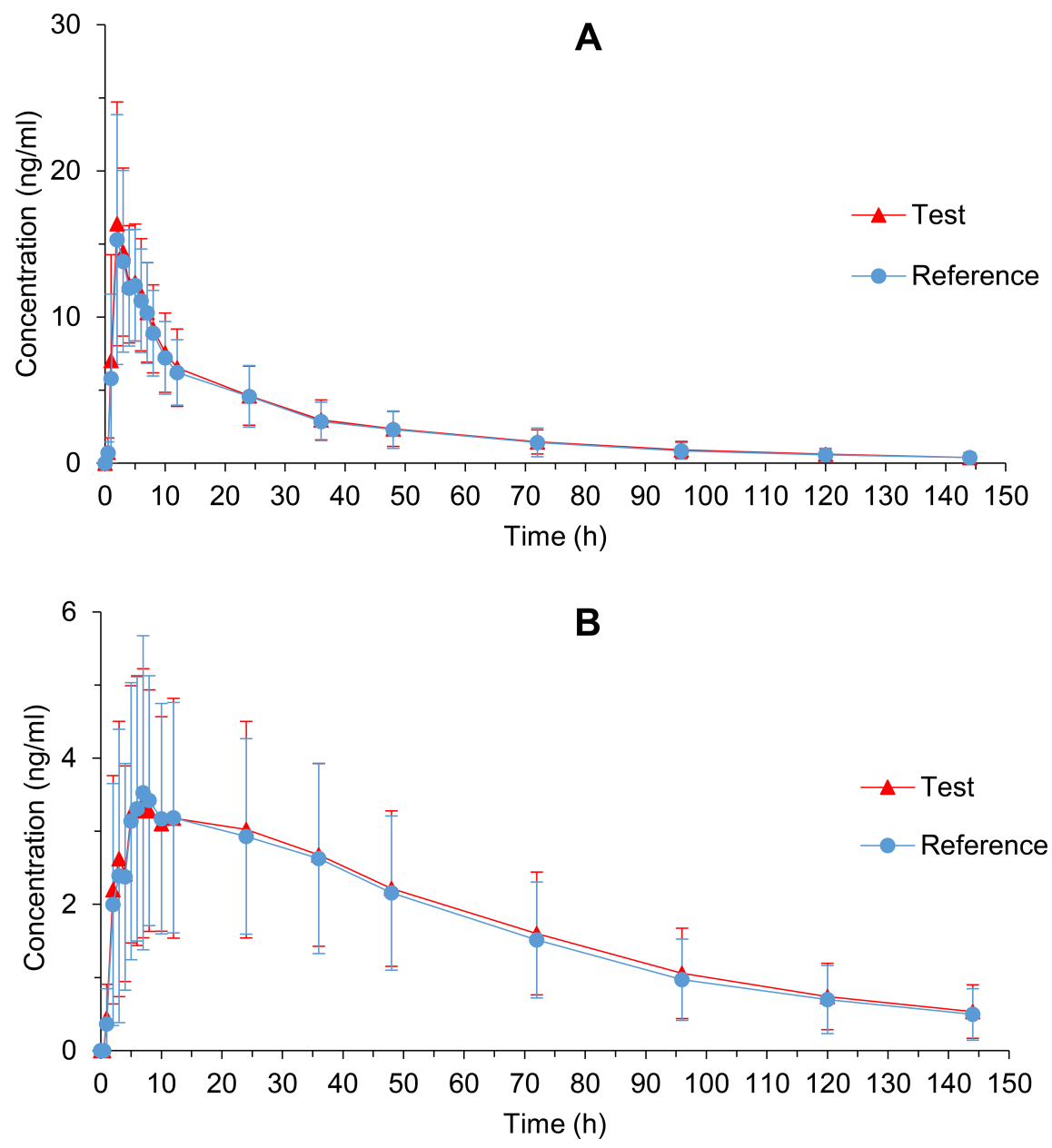

Figure 2 Mean plasma concentration-time profiles of amitriptyline (A) and nortriptyline (B) after single oral administration of reference and test amitriptyline hydrochloride tablet in 24 healthy Chinese volunteers under fasting condition. Data represent the mean value for the 24 volunteers, and error bars represent the SD. 

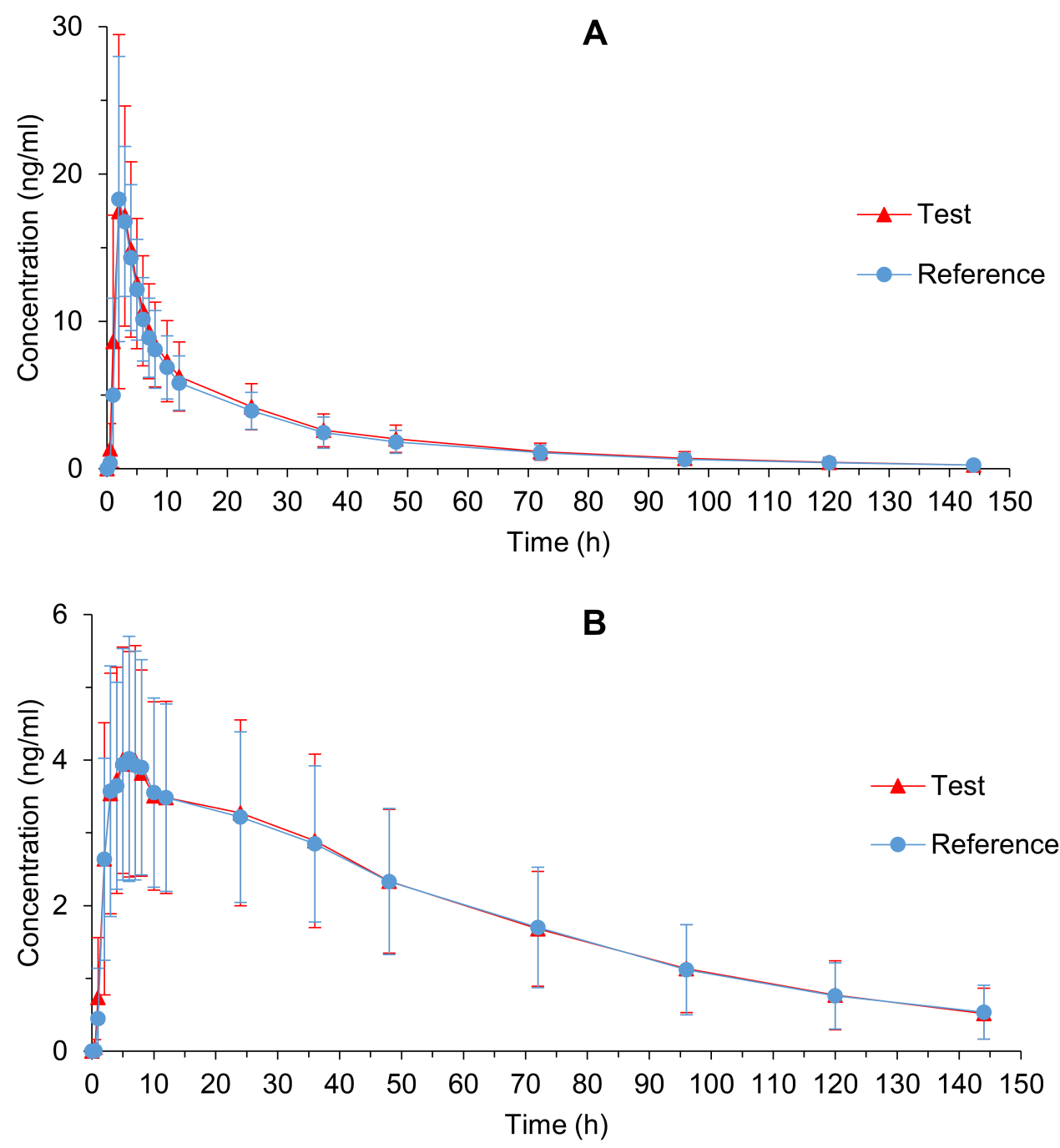

Figure 3 Mean plasma concentration-time profiles of amitriptyline $(\mathbf{A})$ and nortriptyline $(\mathbf{B})$ after single oral administration of reference and test amitriptyline hydrochloride tablet in 24 healthy Chinese volunteers under fed condition. Data represent the mean value for the 24 volunteers, and error bars represent the SD.

$\mathrm{AUC}_{0-\mathrm{t}}$, and $\mathrm{AUC}_{0-\infty}$ of amitriptyline in both fasting and under both fasting and fed conditions showed no signififed conditions. Statistical analysis of $t_{1 / 2}$ and $T_{\max }$ for cant difference when using the non-parametric method amitriptyline between the test and reference products $(P>0.05)$. However, the $\mathrm{t}_{1 / 2}$ of nortriptyline was

Table 3 Pharmacokinetic Parameters of Amitriptyline and Nortriptyline After Single Oral Administration of Test and Reference Amitriptyline Hydrochloride Tablet Under Fasting Condition

\begin{tabular}{|c|c|c|c|c|c|c|}
\hline \multirow[t]{2}{*}{ Parameter } & \multicolumn{3}{|c|}{ Amitriptyline } & \multicolumn{3}{|c|}{ Nortriptyline } \\
\hline & $\mathbf{N}$ & Test & Reference & $\mathbf{N}$ & Test & Reference \\
\hline $\mathrm{T}_{\max }(\mathrm{h})^{\mathrm{a}}$ & 24 & 2.004 (1.99I, 7.014) & $2.003(1.988,6.997)$ & 24 & $7.000(1.998,36.001)$ & $6.997(1.997,35.998)$ \\
\hline$C_{\max }(n g / m L)^{b}$ & 24 & $17.703 \pm 7.335(41.43)$ & $|7.622 \pm 7.02|(39.84)$ & 24 & $3.857 \pm 1.899(49.24)$ & $3.910 \pm 2.140(54.73)$ \\
\hline $\mathrm{AUC}_{0-\mathrm{t}}(\mathrm{ng} \mathrm{h} / \mathrm{mL})^{\mathrm{b}}$ & 24 & $365.525 \pm 157.052(42.97)$ & $352.447 \pm 158.617(45.00)$ & 24 & $246.906 \pm 120.434(48.78)$ & $238.320 \pm 113.153(47.48)$ \\
\hline $\mathrm{AUC}_{0-\infty}(\mathrm{ng} \mathrm{h} / \mathrm{mL})^{\mathrm{b}}$ & 24 & $391.392 \pm 176.886(45.19)$ & $379.483 \pm 184.654(48.66)$ & $19^{c}$ & $276.086 \pm 157.79 \mid(57.15)$ & $260.143 \pm|44.56|(55.57)$ \\
\hline AUC_\%Extrap_obs $(\%)^{\mathrm{b}}$ & 24 & $6.10 \pm 2.61(42.83)$ & $6.32 \pm 2.77(43.84)$ & $19^{c}$ & $9.97 \pm 4.33(43.38)$ & $8.84 \pm 4.21(47.66)$ \\
\hline$\lambda_{z}(\mathrm{~L} / \mathrm{h})^{\mathrm{b}}$ & 24 & $0.0190 \pm 0.0042(22.16)$ & $0.0190 \pm 0.0049(25.69)$ & $19^{c}$ & $0.0176 \pm 0.0038(21.43)$ & $0.0187 \pm 0.0039(21.11)$ \\
\hline$t_{1 / 2}(h)^{b}$ & 24 & $38.428 \pm 9.483(24.68)$ & $38.684 \pm 9.631$ (24.90) & $19^{c}$ & $4|.277 \pm 9.34|(22.63)$ & $38.813 \pm 8.620(22.21)$ \\
\hline
\end{tabular}

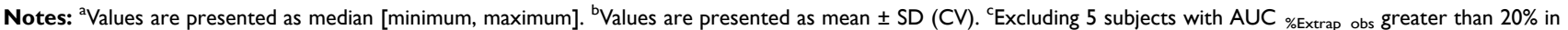
both periods. The results do not include the parameters in the period when AUC_\%Extrap_obs is greater than $20 \%$. 
Table 4 Pharmacokinetic Parameters of Amitriptyline and Nortriptyline After Single Oral Administration of Test and Reference Amitriptyline Hydrochloride Tablet Under Fed Condition

\begin{tabular}{|c|c|c|c|c|c|c|}
\hline \multirow[t]{2}{*}{ Parameter } & \multicolumn{3}{|c|}{ Amitriptyline } & \multicolumn{3}{|c|}{ Nortriptyline } \\
\hline & $\mathbf{N}$ & Test & Reference & $\mathbf{N}$ & Test & Reference \\
\hline $\mathrm{T}_{\max }(\mathrm{h})^{\mathrm{a}}$ & 24 & $1.999(0.994,4.994)$ & $1.999(0.998,4.998)$ & 24 & $4.997(|.995,12.03|)$ & $4.998(1.992,9.994)$ \\
\hline $\mathrm{C}_{\max }(\mathrm{ng} / \mathrm{mL})^{\mathrm{b}}$ & 24 & $21.589 \pm 9.048(41.91)$ & $20.705 \pm 7.852(37.92)$ & 24 & $4.448 \pm 1.631(36.67)$ & $4.547 \pm 1.590(34.97)$ \\
\hline $\mathrm{AUC}_{0-\mathrm{t}}(\mathrm{ng} \mathrm{h} / \mathrm{mL})^{\mathrm{b}}$ & 24 & $334.839 \pm|34.53|(40.18)$ & $312.904 \pm 112.537(35.97)$ & 24 & $267.684 \pm 108.857(40.67)$ & $266.382 \pm 108.202(40.62)$ \\
\hline $\mathrm{AUC}_{0-\infty}(\mathrm{ng} \mathrm{h} / \mathrm{mL})^{\mathrm{b}}$ & 24 & $352.609 \pm I 42.852(40.5 I)$ & $331.621 \pm 119.642(36.08)$ & $22^{c}$ & $282.176 \pm 115.222(40.83)$ & $293.875 \pm 123.130(41.90)$ \\
\hline AUC_\%Extrap_obs $(\%)^{\mathrm{b}}$ & 24 & $4.90 \pm 2.01(4 I .07)$ & $5.57 \pm 2.18(39.04)$ & $22^{c}$ & $9.45 \pm 4.82(51.02)$ & $9.70 \pm 4.56(46.95)$ \\
\hline$\lambda_{z}(\mathrm{~L} / \mathrm{h})^{\mathrm{b}}$ & 24 & $0.0230 \pm 0.0066(28.79)$ & $0.0224 \pm 0.0070(31.28)$ & $22^{c}$ & $0.0187 \pm 0.0050(26.72)$ & $0.0184 \pm 0.0048(26.23)$ \\
\hline $\mathrm{t}_{\mathrm{l} / 2}(\mathrm{~h})^{\mathrm{b}}$ & 24 & $32.459 \pm 9.170(28.25)$ & $33.733 \pm 9.853(29.21)$ & $22^{c}$ & $39.539 \pm 9.744(24.64)$ & $39.860 \pm 8.847(22.20)$ \\
\hline
\end{tabular}

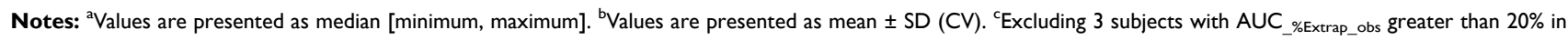
one or two periods. The results do not include the parameters in the period when AUC_\%Extrap_obs is greater than $20 \%$.

Table 5 Geometric Mean Ratios (GMR) and the Corresponding 90\% Cls for the Primary Pharmacokinetic Parameters of Amitriptyline and Nortriptyline Under Fasting Condition

\begin{tabular}{|c|c|c|c|c|c|c|c|}
\hline Parameter & $\mathbf{N}$ & $\begin{array}{l}\text { Geometric } \\
\text { Mean (Test) }\end{array}$ & $\begin{array}{l}\text { Geometric Mean } \\
\text { (Reference) }\end{array}$ & $\begin{array}{l}\text { GMR (Test/ } \\
\text { Reference) }\end{array}$ & $\begin{array}{l}\text { Intra- } \\
\text { Subject CV }\end{array}$ & $90 \% \mathrm{Cl}(\%)$ & $\begin{array}{l}\text { Power } \\
\text { (\%) }\end{array}$ \\
\hline \multicolumn{8}{|l|}{ Amitriptyline } \\
\hline $\mathrm{C}_{\max }(\mathrm{ng} / \mathrm{mL})$ & 24 & 16.56 & 16.57 & 99.95 & 21.08 & $90.14 \sim 110.83$ & 94.82 \\
\hline $\mathrm{AUC}_{0-\mathrm{t}}(\mathrm{ng} \mathrm{h} / \mathrm{mL})$ & 24 & 338.86 & 328.21 & 103.25 & 8.27 & $99.10 \sim 107.56$ & $>99.99$ \\
\hline $\mathrm{AUC}_{0-\infty}(\mathrm{ng} \mathrm{h} / \mathrm{mL})$ & 24 & 361.00 & 350.51 & 102.99 & 8.54 & $98.73 \sim 107.44$ & $>99.99$ \\
\hline \multicolumn{8}{|l|}{ Nortriptyline } \\
\hline $\mathrm{C}_{\max }(\mathrm{ng} / \mathrm{mL})$ & 24 & 3.41 & 3.42 & 99.57 & 9.30 & $95.09 \sim 104.26$ & $>99.99$ \\
\hline$A U C_{0-\mathrm{t}}(\mathrm{ng} \mathrm{h} / \mathrm{mL})$ & 24 & 218.04 & 212.16 & 102.77 & 7.10 & $99.22 \sim 106.45$ & $>99.99$ \\
\hline $\mathrm{AUC}_{0-\infty}(\mathrm{ng} \mathrm{h} / \mathrm{mL})$ & $19^{a}$ & 235.31 & 226.08 & 104.08 & 7.88 & $99.50 \sim 108.87$ & $>99.99$ \\
\hline
\end{tabular}

Notes: ${ }^{a}$ Excluding 5 subjects with AUC_\%Extrap_obs greater than $20 \%$ in both periods. The results do not include the parameters in the period when AUC_\%Extrap_obs is greater than $20 \%$.

Table 6 Geometric Mean Ratios (GMR) and the Corresponding 90\% Cls for the Primary Pharmacokinetic Parameters of Amitriptyline and Nortriptyline Under Fed Condition

\begin{tabular}{|c|c|c|c|c|c|c|c|}
\hline Parameter & $\mathbf{N}$ & $\begin{array}{l}\text { Geometric } \\
\text { Mean (Test) }\end{array}$ & $\begin{array}{l}\text { Geometric Mean } \\
\text { (Reference) }\end{array}$ & $\begin{array}{l}\text { GMR (Test/ } \\
\text { Reference) }\end{array}$ & $\begin{array}{l}\text { Intra- } \\
\text { Subject CV }\end{array}$ & $90 \% \mathrm{Cl}(\%)$ & $\begin{array}{l}\text { Power } \\
\text { (\%) }\end{array}$ \\
\hline \multicolumn{8}{|l|}{ Amitriptyline } \\
\hline $\mathrm{C}_{\max }(\mathrm{ng} / \mathrm{mL})$ & 24 & 19.66 & 19.36 & 101.59 & 24.00 & $90.34 \sim 114.23$ & 86.16 \\
\hline$A \cup C_{0-\mathrm{t}}(\mathrm{ng} \mathrm{h} / \mathrm{mL})$ & 24 & 311.37 & 294.85 & 105.60 & 15.00 & $98.07 \sim|13.7|$ & 98.41 \\
\hline $\mathrm{AUC}_{0-\infty}(\mathrm{ng} \mathrm{h} / \mathrm{mL})$ & 24 & 327.48 & 312.33 & 104.85 & 14.34 & $97.69 \sim 112.53$ & 99.36 \\
\hline \multicolumn{8}{|l|}{ Nortriptyline } \\
\hline $\mathrm{C}_{\max }(\mathrm{ng} / \mathrm{mL})$ & 24 & 4.12 & 4.26 & 96.76 & 7.95 & $93.03 \sim 100.64$ & $>99.99$ \\
\hline$A \cup C_{0-t}(n g h / m L)$ & 24 & 244.49 & 242.85 & 100.68 & 7.35 & $97.08 \sim 104.4 \mathrm{I}$ & $>99.99$ \\
\hline$A \cup C_{0-\infty}(\mathrm{ng} \mathrm{h} / \mathrm{mL})$ & $21^{a}$ & 260.61 & 258.27 & 100.91 & 8.76 & $96.31 \sim 105.73$ & $>99.99$ \\
\hline
\end{tabular}

Notes: ${ }^{a}$ Excluding 3 subjects with AUC_\%Extrap_obs greater than $20 \%$ in one or two periods. The results do not include the parameters in the period when AUC_\%Extrap_obs is greater than $20 \%$.

significant different between the test and reference products under fasting condition (Table 8). In the fasting study, 5 subjects whose AUC_\%Extrap_obs for nortriptyline exceeded $20 \%$ in both periods were excluded from the analysis, which may have contributed to the significance of $\mathrm{t}_{1 / 2}$. Amitriptyline undergoes demethylation forming the 
Table 7 Total Number of Adverse Events and Percentage of Healthy Subjects Experiencing Adverse Events in the Fasting or Fed Study. Values are Given as No. (\%)

\begin{tabular}{|c|c|c|c|c|}
\hline \multirow[t]{2}{*}{ Parameter } & \multicolumn{2}{|c|}{ Fasting Condition $(n=24)$} & \multicolumn{2}{|c|}{ Fed Condition $(n=24)$} \\
\hline & Test & Reference & Test & Reference \\
\hline Any adverse event & 83 & & 86 & \\
\hline \multicolumn{5}{|l|}{ Adverse event may relate to drug } \\
\hline $\begin{array}{l}\text { Results of inspection } \\
\text { Increase of alanine aminotransferase } \\
\text { Increase of serum triglyceride } \\
\text { Hyperuricemia } \\
\text { Hyperbilirubinemia } \\
\text { Prolongation of activated partial thromboplastin time } \\
\text { Urine protein positive } \\
\text { Increase of serum total bile acid }\end{array}$ & $\begin{array}{l}5(6.02 \%) \\
\text { I (I.20\%) } \\
\text { I (I.20\%) } \\
\text { I (I.20\%) }\end{array}$ & $\begin{array}{l}2(2.41 \%) \\
2(2.41 \%) \\
2(2.41 \%) \\
I(1.20 \%)\end{array}$ & $\begin{array}{l}\text { I (1.16\%) } \\
3(3.49 \%) \\
\text { I (1.16\%) } \\
\text { I (1.16\%) } \\
\text { I (1.16\%) }\end{array}$ & $\begin{array}{l}3(3.49 \%) \\
I(1.16 \%)\end{array}$ \\
\hline $\begin{array}{l}\text { Cardiac disorders } \\
\text { Sinus Bradycardia } \\
\text { Incidental ventricular extrasystole } \\
\text { Bradycardia }\end{array}$ & $4(4.82 \%)$ & I (1.20\%) & $\begin{array}{l}8(9.30 \%) \\
2(2.32 \%) \\
3(3.49 \%)\end{array}$ & $\begin{array}{l}6(6.98 \%) \\
I(1.16 \%)\end{array}$ \\
\hline $\begin{array}{l}\text { Vascular disorders } \\
\text { Hypotension }\end{array}$ & $2(2.41 \%)$ & $2(2.41 \%)$ & I (I.16\%) & \\
\hline $\begin{array}{l}\text { Gastrointestinal disorders } \\
\text { Nausea } \\
\text { Abdominal pain } \\
\text { Skin and subcutaneous tissue disorders } \\
\text { Papule }\end{array}$ & $\begin{array}{l}3(3.61 \%) \\
I(1.20 \%)\end{array}$ & & ( $1.16 \%)$ & \\
\hline $\begin{array}{l}\text { Nervous system disorders } \\
\text { Drowsiness }\end{array}$ & $22(26.51 \%)$ & $22(26.5 \mid \%)$ & 24 (27.91\%) & $23(26.74 \%)$ \\
\hline $\begin{array}{l}\text { Ear and labyrinth disorders } \\
\text { Vertigo } \\
\text { Tinnitus }\end{array}$ & $\mathrm{I}(\mathrm{I} .20 \%)$ & I (1.20\%) & $\begin{array}{l}\text { I (I.I6\%) } \\
\text { I (I.I6\%) }\end{array}$ & \\
\hline Adverse event may not relate to drug & & & & \\
\hline $\begin{array}{l}\text { Results of inspection } \\
\text { Leukocytosis of urine } \\
\text { Esterase positive in urine leukocytes } \\
\text { Decrease in leukocyte count } \\
\text { Neutrophil count decrease }\end{array}$ & $\begin{array}{l}\text { I (I.20\%) } \\
\text { I (I.20\%) }\end{array}$ & $\begin{array}{l}\text { I (I.20\%) } \\
\text { I (I.20\%) }\end{array}$ & $\begin{array}{l}\text { I (I.16\%) } \\
\text { I (I.16\%) }\end{array}$ & \\
\hline $\begin{array}{l}\text { Cardiac disorders } \\
\text { Sinus tachycardia }\end{array}$ & $2(2.41 \%)$ & $2(2.41 \%)$ & I (I.I6\%) & I (1.16\%) \\
\hline $\begin{array}{l}\text { Skin and subcutaneous tissue disorders } \\
\text { Papule }\end{array}$ & & $\mathrm{I}(\mathrm{I} .20 \%)$ & & \\
\hline
\end{tabular}

major metabolite nortriptyline. ${ }^{14}$ Both amitriptyline and nortriptyline are active pharmaceutical ingredients and treat depression. ${ }^{23}$ According to FDA's Draft Guidance on Amitriptyline Hydrochloride, ${ }^{24}$ the bioequivalence of the test and reference products is primarily determined by pharmacokinetic parameters $\left(\mathrm{C}_{\max }, \mathrm{AUC}_{0-\mathrm{t}}\right.$, and $\left.\mathrm{AUC}_{0-\infty}\right)$ of amitriptyline. The results of nortriptyline confirmed the bioequivalence between the generic and reference drugs.

Under fasting and fed conditions, nortriptyline AUC_\%Extrap_obs values were $>20 \%$ for 5 subjects in both 
Table $8 T_{\max }$ and $T_{1 / 2}$ of Amitriptyline and Nortriptyline After Single Oral Administration of Test and Reference Products Under Fasting or Fed Condition

\begin{tabular}{|c|c|c|c|c|c|c|}
\hline \multirow[t]{2}{*}{ Parameter } & \multicolumn{3}{|l|}{ Amitriptyline } & \multicolumn{3}{|l|}{ Nortriptyline } \\
\hline & Test & Reference & $P$ value & Test & Reference & $P$ value \\
\hline \multicolumn{7}{|c|}{ Fasting Condition } \\
\hline $\begin{array}{l}\mathrm{T}_{\max }(\mathrm{h}) \\
\mathrm{n} \\
\text { Mean (SD) }\end{array}$ & $\begin{array}{l}24 \\
2.835(I .406 I)\end{array}$ & $\begin{array}{l}24 \\
3.209(1.6448)\end{array}$ & 0.5748 & $\begin{array}{l}24 \\
10.625(9.5679)\end{array}$ & $\begin{array}{l}24 \\
10.790(10.0583)\end{array}$ & 0.3263 \\
\hline $\begin{array}{l}\mathrm{t}_{\mathrm{I} / 2}(\mathrm{~h}) \\
\mathrm{n} \\
\text { Mean (SD) }\end{array}$ & $\begin{array}{l}24 \\
38.428(9.4827)\end{array}$ & $\begin{array}{l}24 \\
38.684(9.6307)\end{array}$ & 0.6373 & $\begin{array}{l}19^{\mathrm{a}} \\
4 I .277(9.34 \mathrm{I})\end{array}$ & $\begin{array}{l}19^{\mathrm{a}} \\
38.813(8.6203)\end{array}$ & 0.0289 \\
\hline Fed Condition & & & & & & \\
\hline $\begin{array}{l}\mathrm{T}_{\max }(\mathrm{h}) \\
\mathrm{n} \\
\quad \text { Mean }(\mathrm{SD})\end{array}$ & $\begin{array}{l}24 \\
2.538(1.0620)\end{array}$ & $\begin{array}{l}24 \\
2.455(0.8328)\end{array}$ & 0.3896 & $\begin{array}{l}24 \\
4.915(2.4515)\end{array}$ & $\begin{array}{l}24 \\
5.247(2.327 I)\end{array}$ & 0.5503 \\
\hline $\begin{array}{l}\mathrm{t}_{\mathrm{I} / 2}(\mathrm{~h}) \\
\mathrm{n} \\
\quad \text { Mean (SD) }\end{array}$ & $\begin{array}{l}24 \\
32.459(9.1697)\end{array}$ & $\begin{array}{l}24 \\
33.733(9.8528)\end{array}$ & 0.3277 & $\begin{array}{l}2 I^{\mathrm{b}} \\
38.876(9.463 \mathrm{I})\end{array}$ & $\begin{array}{l}21^{\mathrm{b}} \\
39.338(8.7 \mid 25)\end{array}$ & 0.5113 \\
\hline
\end{tabular}

Notes: ${ }^{a}$ Excluding 5 subjects with AUC_\% Extrap_obs greater than $20 \%$ in both periods. ${ }^{b}$ Excluding 3 subjects with AUC_\%Extrap_obs greater than $20 \%$ in one or two periods.

periods and 3 patients in one or two periods, respectively, possibly due to insufficient blood collection time. Thus, a longer blood collection time may be necessary. In addition, subjects were not affected by the carryover effect since the amitriptyline and nortriptyline concentrations in the 2nd period were less than $5 \% \mathrm{C}_{\max }$, which proved enough washout time.

The pharmacokinetic parameters of amitriptyline in this study were compared with those previously reported. ${ }^{25}$ The observed $\mathrm{C}_{\max }$ for amitriptyline under fasting conditions was similar to previous reported, which validated our results. However, amitriptyline $t_{1 / 2}$ in this study was much longer than what is previously reported $(24 \mathrm{~h})$. Compared to previous reports, $\mathrm{AUC}_{0-\infty}$ increased by approximately $30 \%(296.87 \pm 124.99 \mathrm{ng} \mathrm{h} /$ $\mathrm{mL}$ in the literature), while $\mathrm{T}_{\max }$ decreased by approximately $40 \%$ (the median value of $3.25 \mathrm{~h}$ in the literature).

The pharmacokinetic difference between the parameters of this study and previous studies maybe influenced by different drugs' manufacturers. ${ }^{25}$ The amitriptyline hydrochloride used in literature is produced by Merck \& Co, Inc., while the reference product in here was made by Sandoz Inc., US. Ethnicity difference could also be a reason, since previous studies were conducted using Korean subjects, while Chinese subjects were used in this study. In addition, the analytical determination methods may also play a role. Higher precision of the analytical instrument allows for detection of residual concentrations of chemicals, thus concentration-time curves closer to the actual pharmacokinetic characteristics can be obtained.

Furthermore, pharmacokinetic data under fasting and fed conditions were compared. Tables 3 and 4 indicate that food had an impact on the pharmacokinetic processes of amitriptyline and nortriptyline, regardless of using the test or reference product. With the addition of standard highfat breakfast before administration, $\mathrm{C}_{\max }$ of amitriptyline increased by approximately $20 \%$. Lipophilic amitriptyline could have been absorbed with fat into the lacteals and therefore avoided the liver first-pass effect. In this case, the resulting higher plasma amitriptyline levels might have increased the amitriptyline $\mathrm{C}_{\max } \cdot{ }^{26}$ Conversely, amitriptyline $T_{\max }$ did not significantly change. Food inhibits the rate of gastric emptying, which increased the proportion of drugs dissolved prior to entering the small intestine thus delaying the rate of drug absorption. ${ }^{27}$ The dissolution of lipophilic amitriptyline in bile salt micelles may promote drug absorption. Both the rate of gastric emptying and the lipophilicity of the drug may cause the invariance of $\mathrm{T}_{\max }$. The amitriptyline $\mathrm{t}_{1 / 2}, \mathrm{AUC}_{0-\mathrm{t}}$, and $\mathrm{AUC}_{0-\infty}$ decreased; meanwhile, the nortriptyline $\mathrm{T}_{\max }$ was reduced by approximately $28 \%$, and nortriptyline $\mathrm{C}_{\max }$ and $\mathrm{AUC}_{0-\mathrm{t}}$ and $\mathrm{AUC}_{0-\infty}$ were increased by approximately $15 \%, 10 \%$, and $10 \%$, respectively. One possible explanation is that 
amitriptyline is preferably absorbed in the gastrointestinal tract and is metabolized in the liver. ${ }^{28}$ Food can increase the hepatic-splanchnic blood flow, which may improve the metabolism of amitriptyline to nortriptyline. ${ }^{29}$ This may account for the decreased $t_{1 / 2}, \mathrm{AUC}_{0-\mathrm{t}}$, and $\mathrm{AUC}_{0-\infty}$ values of amitriptyline and the increased bioavailability of nortriptyline in the fed study, which confirms that food affected the pharmacokinetics of amitriptyline.

\section{Conclusion}

This study was conducted under both fasting and fed conditions, in healthy Chinese volunteers. Both the test and reference products complied with the regulatory criteria for supposing bioequivalence based on $\mathrm{C}_{\max }, \mathrm{AUC}_{0-\mathrm{t}}$, and $\mathrm{AUC}_{0-\infty}$. Both products were well tolerated and no serious or unexpected AEs were observed.

\section{Data Sharing Statement}

Individual deidentified participant data is not going to be shared. And all available data has been showed in the article. No other study-related document will be made available.

\section{Funding}

This study was funded by Hunan Dongting Pharmaceutical Co., Ltd. (Hunan, China), the manufacturer of amitriptyline hydrochloride tablets and the National Natural Science Foundation of China (No. 81801644 and No. 81702862).

\section{Disclosure}

Hunan Dongting Pharmaceutical Co., Ltd. (Hunan, China) funded our study, which was the manufacturer of amitriptyline hydrochloride tablets. The funder had not any influence on data collection and analysis, manuscript preparation, and decision to publish. All authors report no conflicts of interest in this work.

\section{References}

1. World Health Organization. Depression and other common mental disorders: global health estimates. License: CC BY-NC-SA 3.0 IGO; 2017. Available from: http://www.who.int/iris/handle/10665/254610. Accessed March 1, 2019.

2. Carvalho AF, Sharma MS, Brunoni AR, et al. The safety, tolerability and risks associated with the use of newer generation antidepressan drugs: a critical review of the literature. Psychother Psychosom. 2016;85(5):270-288. doi:10.1159/000447034

3. Hillhouse TM, Porter JH. A brief history of the development of antidepressant drugs: from monoamines to glutamate. Exp Clin Psychopharmacol. 2015;23(1):1-21. doi:10.1037/a0038550

4. Pratt LA, Brody DJ, Gu Q. Antidepressant use in persons aged 12 and over: United States, 2005-2008. NCHS Data Brief. 2011;76:1-8.
5. National Center for Health Statistics. Health, United States, 2010: With Special Feature on Death and Dying. Table 95. Hyattsville, MD; 2011.

6. Vezmar S, Miljkovic B, Vucicevic K, et al. Amitriptyline for depression. Cochrane Database Syst Rev. 2007.

7. Barbui C, Hotopf M. Amitriptyline v. the rest: still the leading antidepressant after 40 years of randomised controlled trials. $\mathrm{Br}$ J Psychiatry. 2001;178(2):129-144. doi:10.1192/bjp.178.2.129

8. Cheng Q, Huang J, Xu L, et al. Analysis of time-course, dose-effect, and influencing factors of antidepressants in the treatment of acute adult patients with major depression. Int $J$ Neuropsychopharmacol. 2020;23(2):76-87. doi:10.1093/ijnp/pyz062

9. Thour A, Marwaha R. Amitriptyline. 2020 Apr 20. In: StatPearls [Internet]. Treasure Island (FL): StatPearls Publishing; 2020 Jan-. PMID: 30725910.

10. Lohse MJ, Müller-Oerlinghausen B. Psychopharmaka. In: Schwabe U, Pfaffrath D, editors. Arzneiverordnungsreport 2009. Heidelberg: Springer; 2009:820-864.

11. Personal communication. GPRD. Available from: http://www.gprd. com/2011. Accessed July 21, 2020.

12. WHO Expert Committee. The selection and use of essential medicines. World Health Organ Tech Rep Ser. 2014;985:i-xiv, $1-219$, back cover.

13. Chinese national essential drug catalogue (basic medical and health institutions). China; 2018. Available from: http://www.nhc.gov.cn/ wjw/jbywml/201810/600865149f4740eb8ebe729c426fb5d7.shtml. Accessed July 21, 2020.

14. Breyer-Pfaff $U$. The metabolic fate of amitriptyline, nortriptyline and amitriptylinoxide in man. Drug Metab Rev. 2004;36(3-4):723-746.

15. Krüger R, Hölzl G, Kuss HJ, et al. Comparison of the metabolism of the three antidepressants amitriptyline, imipramine, and chlorimipramine in vitro in rat liver microsomes. Psychopharmacology (Berl). 1986;88(4):505-513. doi:10.1007/BF00178516

16. UpToDate. Tricyclic and tetracyclic drugs: pharmacology, administration, and side effects; 2016 [cited August 2, 2016]. Available from: https://www.uptodate.com/contents/tricyclic-and-tetracyclic-drugspharmacology-administration-andsideeffects? source $=$ machineLearning\&search=tricyclic + antidepressants\&selectedTitle $=1$ $\sim 150$ \&sectionRank $=2 \&$ anchor $=H 31$-references. Accessed July 21, 2020.

17. Moore RA, Derry S, Aldington D, et al. Amitriptyline for neuropathic pain in adults. Cochrane Database Syst Rev. 2015;2015(7): CD008242.

18. Hiroki T, Suto T, Saito S, et al. Repeated administration of amitriptyline in neuropathic pain: modulation of the noradrenergic descending inhibitory system. Anesth Analg. 2017;125(4):1281-1288. doi:10.1213/ANE.0000000000002352

19. Rico-Villademoros F, Slim M, Calandre EP. Amitriptyline for the treatment of fibromyalgia: a comprehensive review. Expert Rev Neurother. 2015;15(10):1123-1150. doi:10.1586/14737175.2015.1091726

20. Rampello L, Alvano A, Chiechio S, et al. Evaluation of the prophylactic efficacy of amitriptyline and citalopram, alone or in combination, in patients with comorbidity of depression, migraine, and tension-type headache. Neuropsychobiology. 2004;50(4):322-328. doi: $10.1159 / 000080960$

21. Burch R. Antidepressants for preventive treatment of migraine. Curr Treat Options Neurol. 2019;21(4):18. doi:10.1007/s11940019-0557-2

22. AMITRIPTYLINE HYDROCHLORIDE-amitriptyline hydrochloride tablet, film coated. Durham, NC: Inc, A.H.; 2016. Available from: https://dailymed.nlm.nih.gov/dailymed/drugInfo. cfm?setid=1e6d2c80-fbc8-444e-bdd3-6a91 fe1b95bd. Accessed July $21,2020$.

23. Hicks JK, Swen JJ, Thorn CF, et al. Clinical pharmacogenetics implementation consortium guideline for CYP2D6 and CYP2C19 genotypes and dosing of tricyclic antidepressants. Clin Pharmacol Ther. 2013;93(5):402-408. doi:10.1038/clpt.2013.2 
24. Draft Guidance on Amitriptyline Hydrochloride. US Food and Drug Administration. USA. Available from: https://www.accessdata.fda. gov/drugsatfda_docs/psg/Amitriptyline_HCl_tab_85966_85969_ 85968_85971_85967_85970_RC3-10.pdf. Accessed March 2010.

25. Nam Y, Lim CH, Lee HS, et al. Single-dose, randomized, open-label, 2-way crossover study of the pharmacokinetics of amitriptyline hydrochloride 10- and 25-mg tablet in healthy male Korean volunteers. Clin Ther. 2015;37(2):302-310. doi:10.1016/j.clinthera.2014.09.010

26. Burch JE, Hullin RP. Amitriptyline pharmacokinetics. A crossover study with single doses of amitriptyline and nortriptyline. Psychopharmacology (Berl). 1981;74(1):35-42. doi:10.1007/BF00431754

27. Charman WN, Porter CJ, Mithani S, et al. Physiochemical and physiological mechanisms for the effects of food on drug absorption: the role of lipids and pH. J Pharm Sci. 1997;86(3):269-282. doi:10.1021/js960085v
28. Bae SK, Yang KH, Aryal DK, et al. Pharmacokinetics of amitriptyline and one of its metabolites, nortriptyline, in rats: little contribution of considerable hepatic first-pass effect to low bioavailability of amitriptyline due to great intestinal first-pass effect. $J$ Pharm Sci. 2009;98(4):1587-1601. doi:10.1002/jps.21511

29. McLean AJ, McNamara PJ, duSouich P, et al. Food, splanchnic blood flow, and bioavailability of drugs subject to first-pass metabolism. Clin Pharmacol Ther. 1978;24(1):5-10. doi:10.1002/cpt19782415

\section{Publish your work in this journal}

Drug Design, Development and Therapy is an international, peerreviewed open-access journal that spans the spectrum of drug design and development through to clinical applications. Clinical outcomes, patient safety, and programs for the development and effective, safe, and sustained use of medicines are a feature of the journal, which has also been accepted for indexing on PubMed Central. The manuscript management system is completely online and includes a very quick and fair peer-review system, which is all easy to use. Visit http://www. dovepress.com/testimonials.php to read real quotes from published authors. 